\title{
European Industrial Energy Intensity: Innovation, Environmental Regulation, and Price Effects
}

\author{
Victor Ajayi ${ }^{a *}$ and David Reiner ${ }^{a}$
}

\begin{abstract}
We investigate the direct role of technological innovation and other factors influencing industrial energy intensity across 17 EU countries over 1995-2009. We develop an innovative industry-level patent dataset and find compelling evidence that patent stock negatively influences industrial energy intensity. In particular, we find a much stronger effect of patent stock on energy-intensive industries with an estimated coefficient of -0.138 which almost double that of less energy-intensive industries (estimated at -0.085 ). While our results show that energy price remains the major determinant of energy intensity, the chemicals industry, which is not covered by the EU Emissions Trading Scheme (ETS) during the sample period, appears more susceptible to energy prices relative to other energy-intensive industries that are covered by the EU ETS. Exploring regional differences in carbon taxation, we find a significant decline in energy intensity in Northern Europe owing to the carbon tax policy implemented in the early 1990s across the Nordic countries.
\end{abstract}

Keywords: Industrial energy intensity, Innovation, Energy price, Carbon tax

https://doi.org/10.5547/01956574.41.4.vaja

\section{INTRODUCTION}

Energy efficiency is often seen as perhaps the most straightforward 'no-regrets' means of delivering energy security, greenhouse gas emissions reductions and decoupling economic growth from rising energy use (Jaffe, Newell \& Stavins, 2004). Moreover, energy efficiency can act as a bulwark against ever-increasing pressure on energy-intensive industries to reduce emissions and energy use in a carbon-constrained world. Rising fuel prices and their impact on industrial competitiveness have made energy efficiency improvements a central focus of EU energy policy. The oil crises of 1973-1974 and 1979 brought energy prices (and hence energy efficiency) to the fore as a crucial concern in national policy-making. More recently, external pressures such as the US shale gas 'revolution' and China's burgeoning steel exports have highlighted the challenges Europe faces in terms of global competitiveness if it is to retain its domestic manufacturing base. In response to the mandate received from the European Council, the European Commission issued a report on energy-intensive industries (like steel, ceramic, chemicals, glass) and documents that the competitiveness of these industries may be at risk as a result of increasing energy prices and transmission costs (CEPS, 2014).

a Energy Policy Research Group, Judge Business School, University of Cambridge, United Kingdom.

* Corresponding author. E-mail: va301@cam.ac.uk, phone: +44 7442335953.

The Energy Journal, Vol. 41, No. 4. This is an open access article under the terms of the Creative Commons Attribution License (CC-BY), which permits use, distribution and reproduction in any medium, provided the original work is properly cited. All rights reserved. 
Faced with the slow recovery of industrial output against the challenge of growing competitive pressures from emerging economies following the Global Financial Crisis, most countries in the EU continue to witness a falling share of their manufacturing sectors (Bernard et al., 2016; Stollinger, 2016). Given that the manufacturing sector is viewed as a key element in industrial strategy and employment in traditional industries in the European Union, many European policymakers seek to avert (or at least attenuate) the decline in manufacturing associated with the wider structural shift towards the service sector, which is becoming more important in all developed countries (Schettkat and Yocarini, 2006; Hofer et at., 2015). This belief hinges on the supposition that a strong industrial base is fundamental to Europe's economic recovery and competitiveness. To remain profitable in a globally competitive environment, in the presence of stringent environmental policies and regulation, European manufacturing firms must constantly increase their productivity performance. Becoming more innovative in term of production and process is one promising way to open new paths in this context. Since the launch of the EU ETS in 2005, there has been considerable debate over leakage, i.e., the extent to which firms would move operations of higher-carbon activities abroad versus inducing European manufacturing firms to develop new emission reducing technological innovation without a corresponding reduction in output (e.g. Sato et al., 2015; Demailly and Quirion, 2006).

Meanwhile, research into energy intensity has tended to focus on the contributions of energy efficiency improvements towards reducing global energy consumption and greenhouse emissions. Evidence of technological efficiency effect in decreasing aggregate energy intensity is documented in a number of studies, including Welsch and Ochsen (2005), Metcalf (2008), Zhang (2013), Voigt et al. (2014), Parker and Liddle (2016), and Karimu et al. (2017). Moreover, several previous studies also allude to the fact that structural effects can have an impact on the energy intensity change (see Unander, 2007; Lescaroux, 2008; Huntington, 2010; Mulder and de Groot, 2012; Mulder et al., 2014). This has necessitated using other perspectives beyond the traditional approach of technological and structural effects to further investigate the factors influencing energy intensity. Investigating the factors contributing to declining energy intensity is usually based on regression analysis following decomposition of the total energy intensity into efficiency and structural effects. However, while the technological efficiency effect and the structural effect separately affect aggregate energy intensity change, the existing literature reveals an obvious neglect of the direct role of technological innovation on energy intensity. ${ }^{1}$ Furthermore, even though technological efficiency change is adjudged to be an important driver of the change in energy intensity, the index number approach does not account for the contribution coming from this source (Ma et al., 2009). To the extent that decomposition analyses provide important insights regarding the overall intensity of energy consumption, as well as the structure of the economy, subsectoral energy intensity is directly linked with production which tends to be impacted more specifically by policy actions.

Subsectors also differ in terms of energy required relative to other inputs like capital and labour (Mulder and Groot, 2012). Therefore, gaining a comprehensive understanding of the factors influencing energy intensity (i.e., energy consumption per unit of output) at the industrial level is crucial. Moreover, this analysis is all the more important considering the high degree of variation in energy intensity across industries, ranging from 40.70 TJ/ \$million PPP (1995\$) in chemical industry to $1.87 \mathrm{TJ} /$ \$million PPP in electrical and optical equipment industry. ${ }^{2}$ For example, evidence of

1. Perhaps, this dearth of studies can be explained by the lack of sector-level data on innovation activities such as patents in manufacturing industries, which has made its inclusion difficult in previous empirical studies (Gallagher et al., 2012).

2. Average energy intensity is calculated by averaging the energy intensity across industry from 1995-2009. See Appendix Figure A1 for the industrial energy intensity bar chart. 
varying impact of technological innovation on energy intensity in different industries could indicate that certain industries possess greater or lesser ability to undertake more ambitious decarbonization efforts and might require tailored intervention. This could provide useful information for policymakers on the design and implementation of fiscal incentives for enhancing further energy conservation and targeting new emission-reducing technologies.

We offer four main contributions in this study. First, we have developed a unique industry-level patent dataset to investigate the determinants of industrial energy intensity across European manufacturing industries. As such, patent stock provides insight into the interplay of energy prices and technological innovation on energy intensity. Second, building on the existing energy demand literature, we consider asymmetric response of industrial energy intensity to price by decomposing energy price into three components. Third, we explore heterogeneities across industry categories, with special focus on energy-intensive industries and less energy-intensive industries. Taking into account that subsectors of manufacturing differ in important respects from each other in term of intensity of energy use, hence their reasonable classification as energy-intensive and less energy-intensive industries. Finally, we compare regional industrial energy intensity analysis by accounting for inter-regional differences, notably the presence or absence of a carbon tax.

The remainder of the paper is structured as follows. In the next section, we provide a brief literature review of previous studies that examine the determinants of energy intensity. We describe our methodological approach in greater detail in Section 3. The data used are presented and discussed in Section 4. In Section 5 we present the results, while Section 6 offers some conclusions and points to some important policy implications.

\section{RELATED LITERATURE}

Our study draws on two different strands of the academic literature that have each been well studied in their own right, but which have not intersected much - aggregate energy intensity found in single or multi-country context and asymmetric price response, usually employed in energy demand literature. Indeed, there is now a large body of work on energy intensity and its determinants, usually using a two-stage approach comprising index decomposition analysis technique and econometric techniques to examine on the relationship between energy intensity indices and their determinants ${ }^{3}$. These studies span a wide range of countries and time periods over the last three decades, including both multiple and single-country studies. The change in energy intensity at the aggregate level is found to occur through two basic sources. The change in sectoral energy productivity due to technological improvements, and structural change which involves shifting production between sub-sectors, especially from energy-intensive manufacturing industries towards less energy-intensive service sectors.

Many of the multi-country studies on economy-wide aggregate change in energy intensity analysis, for example, Oseni (2009); Zhang (2013); Jimenez and Mercado (2014); Mulder et al. (2014) and Atalla and Bean (2017), identify energy prices and per capita income as the main determinants of energy intensity. Examining energy determinants for 16 Organisation of Economic Cooperation and Development (OECD) countries, Oseni (2009) concludes that long-run reduction in energy intensity as a result of energy prices and income is largely due to movement away from energy-intensives activities and toward the less energy-intensive service sector. Drawing on 75 countries, Jimenez and Mercado (2014) show that per capita income, petroleum prices, fuel-energy mix,

3. The two commonly used methods are the Fisher Ideal index and the Logarithmic Mean Divisia Index (LMDI). See Ang and Zhang, 2000 for a detailed literature survey on index number decomposition analysis. 
and GDP growth are the factors contributing to energy intensity with clear correlation with structural economic shift. They conclude that Latin American countries experience decline in energy intensity around $20 \%$ during the sample period which was regarded as underperformance. Atalla and Bean (2017) estimate the determinants of energy productivity in 39 countries and confirm that higher levels of income per capita and higher energy prices are associated with greater energy productivity, while a greater share of output from industry is associated with lower energy productivity levels.

Single-country studies on aggregate energy intensities include those of Metcalf (2008), Song and Zheng (2012) and $\mathrm{Wu}$ (2012), all of which find a marked reduction in energy intensity during the sample period and identify efficiency as the major driver responsible for decreasing energy intensity. Metcalf (2008) decompose state-level energy intensity changes occurring in the United States and econometrically examine the decomposition indexes in a panel analysis. In line with the earlier findings, Metcalf (2008) confirms that rising per capita income and energy prices significantly contribute to energy efficiency improvements but are not associated with structural economic shift. Using a provincial-level panel data set, Song and Zheng (2012) adopt an econometric approach to examine the driving forces behind China's changing energy intensity from 1995 to 2009. They surmise that rising income plays a vital role in reducing energy intensity while increasing urbanization threatens energy intensity improvements. Wu (2012) further confirms that increasing income per capita and energy price led to a reduction in efficiency in China during over 1997-2007.

Sectoral studies include Lescaroux (2008) on the US manufacturing sector using two-digit SIC level data and Mulder (2014) on the determinants of energy intensity in the Dutch service sector. The common factor in all these studies is that price played an important role in explaining the decline in energy intensity. Zhang (2013) also shows that income growth and energy price increases were the main drivers of energy intensity, while the impact of trade is positively related to energy intensity in the manufacturing sector in Eastern Europe. In contrast to the studies on the two-stage approach, Hang and Tu (2007), Fisher-Vanden et al. (2016) and Verbic et al. (2017) use only econometrics approach to investigate the determinants of energy intensity. In particular, Fisher-Vanden et al. (2016) consider four Chinese energy-intensive industries in examining the factors influencing energy intensity and conclude that in all four industries, energy prices and technology ${ }^{4}$ are significant contributors to the decline in energy intensity.

With respect to asymmetric price response, the energy demand literature has established that price changes may be asymmetric owing to the long life of capital and price-induced technical change (Gately and Huntington, 2002; Griffin and Schulman, 2005; Huntington, 2006; Adeyemi and Hunt 2007, 2014; Olaniyan and Evans, 2014). It is therefore surprising that only a couple of papers (see Lescaroux, 2008 and Parker and Liddle, 2016), have attempted to examine this relationship between prices and efficiency. Lescaroux (2008) confirms the asymmetric response of energy intensity to prices, emphasizing that price rises are associated with more efficiency improvements than those lost when prices fall. However, Parker and Liddle (2016) find no statistically significant relationship between asymmetric price and energy intensity and conclude that the direction of price movement may not matter to energy intensity.

Unlike Parker and Liddle (2016) who consider only upward and downward price movement, we adopt the traditional price decomposition approach following Adeyemi and Hunt (2007, 2014) and disaggregate energy price into three phases: price maximum (maximum historical prices), price recovery (sub-maximum increases) and price cut, which is meant to reflect any endogenous

4. Fisher-Vanden et al. (2016) employ R\&D expenditures as proxy for technological innovation. However, R\&D is a measure of inputs, and takes no account of the productivity and effectiveness of effort (See Griffith et al., 2006). 
effect of technological progress. This approach enables us to disentangle the effect of changing oil prices during the low-price period prior to 2004 and the period of marked oil price increases over 2004-2008, which culminated in the historical high reached in July 2008 just before the onset of the Global Economic Crisis 5 . The interactions between technological innovation and the price components can lead to varying direct price-induced innovation in the manufacturing sector owing to the argument that the energy demand response to an increase in the maximum price is not necessarily the same as the response to a price recovery. Hence, understanding these interactions allow policymakers to revise their policies to achieve their objectives as a result of price changes.

Based on the literature review, we find four fundamental issues unaddressed in the existing studies and we seek to fill these gaps. First, there is an obvious neglect of the direct impacts of innovation with respect to both energy intensity and energy demand. Second, no study has considered asymmetric response of industrial energy intensity to price by decomposing energy price into three components. Third, the existing literature does not account for subsectoral heterogeneities in the analysis of energy intensity. Finally, none of the existing studies have considered differences across EU countries despite the historical diversity in their energy and climate change policies.

\section{METHODOLOGY AND HYPOTHESES}

Our aim is to investigate the factors influencing energy intensity in the EU manufacturing sector. Many factors have been widely acknowledged to influence industrial energy intensity and the approach adopted here is similar to that of Fisher-Vanden et al. (2016). We lay out below a set of relevant hypotheses to examine the impact of key economic factors in the EU manufacturing sector. These testable hypotheses are discussed under following general categories - energy prices; technological innovation; capital intensity; trade openness; regional differences; and exposure to carbon taxation.

The arguments behind why these determinants of energy intensity such as an increase in energy prices may lead to lower energy intensity has been well studied since higher prices are expected to lead to lower energy consumption (see Parker and Liddle, 2016; Mulder and Groot, 2012, 2014). Hence, we propose the following hypothesis:

H1: We expect energy prices, ceteris paribus, to have a significant and negative relationship with energy intensity. In particular, we expect energy-intensive industries to respond more aggressively by lowering their energy intensity more than less energy-intensive industries in response to higher energy prices.

Closely allied to increases in energy prices is the impact of technological innovation on energy intensity. In practice, technical innovation in manufacturing industries might not be realized without an effective driving force in which pricing plays an important role. The increase in cost of energy could lead to the development of more energy-efficient technologies (Birol and Keppler, 2000).

H2.1: New technological innovation potentially enhances higher output using the same level of inputs, thereby reducing energy intensity. We expect that technology improvements in specific processes and products, proxied by patent stock, will lead to a decline in

5. Although energy price includes all forms of energy other than oil, the emphasis on oil prices is only an indication of high volatility experienced by oil prices relative to other energy prices during the financial crises. In Tables A4-A7 in the Appendix, we conduct a sensitivity analysis where we omit 2008-9, but find no major qualitative differences from the full time series. 
energy intensity. Faced with the need to adopt low-carbon technologies, we also expect energy-intensive industries to generate, ceteris paribus, more patents, thereby leading to a greater impact in reducing energy intensity relative to less energy-intensive industries.

H2.2: The interplay between energy prices and innovation will result in substantial energy intensity reduction as firms are expected to react to an increase in energy prices by scaling up their investments in technological innovation. This interplay is proxied by the interaction of price and patent stock.

Capital accumulation of more energy-efficient capital stock due to new technology is also crucial to reducing energy intensity. Popp (2001) posits that firms made costly adjustments to capital, despite the fall in energy prices in the early1980s, because the new technology, which was developed in response to the energy crisis, was better than the previously existing technology. Earlier studies, such as Thompson and Taylor (1995) and Steinbuks and Neuhoff (2014) confirm the degree of substitution between energy and capital. Specifically, Thompson and Taylor (1995) establish that capital and energy are substitutes in both the short and long run based on the estimates of the Morishima elasticity of substitution. Metcalf (2008) further argues that energy and technology may be substitutes in production. Thus, regardless of energy prices, technology-induced investment can contribute to reducing energy intensity.

H3: As a plausible means by which energy-efficient technologies can influence energy intensity, we expect capital intensity, proxied as the capital-labor ratio, to be negatively related to energy intensity. As more capital is geared toward more advanced production technologies, especially in energy-intensive industries, energy efficiency improves.

Trade openness has been considered as a channel for foreign technological spillovers in reducing energy consumption (Liao et al., 2009). This dates back to the work of Coe and Helpman (1995) which establish that technology spills over across countries via trade flows. Trade could also subject firms to a higher level of competition and encourage the development of cost-cutting strategies, which will encourage energy savings (EBRD, 2010). Technological diffusion via trade openness can stimulate domestic innovation and engender competition in the local economy, which also has implications for reducing energy intensity.

H4: Trade openness is expected to play an important role in explaining differences in energy intensity in the EU manufacturing sector. In more trade-exposed energy-intensive industries such as steel (basic metals), we expect a negative relationship with energy intensity in order for firms in the industries to remain competitive and maintain their market share in the international markets.

All the 17 sampled countries in the study are part of the European Union and are subject to the same institutional framework, policies and directives (such as those on energy efficiency and climate change targets). We expect though that in addition to the likely national differences in how policies are implemented driven by country-specific circumstance, there may also be strong regional effects. There are clear groupings within the group of countries in terms of common history, level of development, industrial structure and policy approaches to energy and climate change. Over the course of the period of our study, the regulation of greenhouse gases has increased dramatically at both the national and EU level. In the early 1990s, Finland, followed by Sweden and Denmark imposed relatively high carbon taxes that have continued to this day. Following the Kyoto Protocol in 1997, the EU instituted an EU-wide Emissions Trading Scheme (ETS), which applied to the power 
and some (but not all) of the manufacturing sector. The system began operating in 2005 with a trial period and a full-fledged system from 2008, near the end of our time horizon.

H5.1: We would expect there to be a clear negative relationship between the level of the carbon tax and energy intensity in those countries where a carbon tax has been employed.

H5.2: We expect that subsectors covered by the ETS will exhibit different responses in terms of improvements in energy intensity than other sectors that are not covered. In particular, we expect that energy-intensive sectors within the EU ETS (e.g., metals, pulp and paper) will have a lower price elasticity than those energy-intensive sectors not covered by the ETS (notably chemicals).

\subsection{Panel Data Analysis}

Our dataset is an unbalanced panel consisting of cross-sections of subsectors with a relatively short time series (15 years from 1995-2009). Given that the cross-sections cut across different subsectors in seventeen EU countries, there is the possibility of a range of time invariant country-specific and sector specific-unobserved factors influencing the behavior of each subsector. Hence, we adopt techniques from panel data econometrics, which are best suited to handle this observational-specific heterogeneity that is fixed over time. A distinctive feature of panel data modelling is the treatment of unobserved heterogeneity by simply including time-invariant unobservable individual effects in the model. The two alternative approaches for obtaining unbiased estimated parameters in panel data are to use fixed effects (FE) and random effects (RE) estimators, each of which treats unobserved heterogeneity differently in a model. While the FE estimator deals with such heterogeneity explicitly in the estimation process by putting in a dummy for each individual; otherwise known as the Least Squares Dummy Variables (LSDV) estimator, the RE estimator implicitly recognizes it, and assumes the individual effects are drawn from the same probability distribution thereby making them random and treated as though they were a part of the error term. The FE estimator is always consistent, but the RE estimator, where applicable, is more efficient and becomes more parsimonious as it has fewer parameters. In a fixed effects model, consistency does not require that the individual and error terms are uncorrelated. However, RE estimators do require that the individual effects (and hence the composite error term) are uncorrelated with the explanatory variables for it to be consistent. A specification test based on the comparison of two alternative estimators of the same parameter vector is known as the Hausman test (Hausman, 1978), which is often used to choose the appropriate estimator.

However, since the cross-sections in this dataset represent in twelve industries in seventeen EU countries with distinctive sovereign power, these variations could amount to unobserved heterogeneity. If this unobserved heterogeneity was contained in variables indicative of factors such as climate change regulatory policy, it is highly likely that the unobserved heterogeneity, and hence the individual effects, would be correlated with the independent variables i.e. factors such as climate change regulatory policy could influence explanatory variables. In the event that the strict exogeneity assumption for a RE model is not tenable, only FE estimators would be consistent. We then proceed to investigate the factors influencing energy intensity of the EU manufacturing sector by employing a FE estimator while incorporating time dummies as controls for factors that are constant 
across sectors and countries but vary over time such energy prices. The model specification for the static FE model for industrial energy intensity is as follows: ${ }^{6}$

$$
\begin{aligned}
E I_{i t}= & \beta_{1} P_{i t}+\beta_{2} P A T_{i t}+\beta_{3} O P E N_{i t}+\beta_{4} G R O W T H_{i t}+\beta_{5}(K / L)_{i t}+\beta_{6} P_{i t} * P A T_{i t} \\
& +\delta_{i} D_{t}+\alpha_{i}+\varepsilon_{i t}
\end{aligned}
$$

where $i$ represents subsectors, $i=1, \ldots, 12$, and $t$ represents the years 1995-2009. $E I_{i t}$ is the $\log$ of aggregate energy intensity, $P_{i t}$ is the log of energy price, $P A T_{i t}$ is the log of patent stock, GROWTH is the growth rate of value added, $O P E N_{i t}$ is the degree of trade openness, $(K / L)_{i t}$ is log of capital intensity, $P_{i t} * P A T_{i t}$ is the interaction between patent stock and energy price. The $\alpha_{i}$ term is a country fixed effect that allows for unobserved heterogeneity, $D_{t}$ is the year dummy capturing any time effect while $\varepsilon_{i t}$ is the idiosyncratic random error.

\subsection{Asymmetric Price Response}

Past energy demand studies (see Dargay and Gately 1995; Gately and Huntington, 2002; Griffin and Schulman, 2005; and Huntington, 2006; Adeyemi and Hunt 2007, 2014; Olaniyan and Evans, 2014) have shown that energy prices have imperfect reversibility such that the responsiveness of demand in periods of high energy prices differs from the responsiveness in periods of falling prices. More importantly, these asymmetric price movements affect the level of technological change as higher prices tend to induce innovation or installation of more efficient capital stock which has important implications for energy intensity.

Drawing on these studies, we decompose energy prices into three different components to examine the asymmetric response of energy price. Energy prices in this study (the log of real subsector prices) are decomposed into three categories which are price maximum $\left(P^{\max }\right)$, price cut $\left(P^{c u t}\right)$ and price recovery $\left(P^{r e c}\right)$ as follows:

$$
P_{t}=P_{1}+P_{t}^{\max }+P_{t}^{c u t}+P_{t}^{r e c}
$$

where:

$P_{t}$ is the $\log$ of energy price

$P_{1}$ is the log of price in the initial year, $t=1$;

$P_{t}^{\max }$ i.e. the cumulative increase in log of maximum historical prices and is monotonically non-decreasing, $P_{t}^{\max } \geq 0$

$P_{t}^{c u t}$ i.e. the cumulative decrease in log of prices; monotonically non-decreasing, $P_{t}^{\text {cut }} \leq 0$

$P_{t}^{r e c}$ i.e. the cumulative sub-maximum increase in log of prices; monotonically non-decreasing, $P_{t}^{r e c} \geq 0$

Therefore:

$$
\begin{aligned}
& P_{t}^{\max }=\sum\left\{\max \left(P_{1}, \ldots, P_{t}\right)-\max \left(P_{1}, \ldots, P_{t-1}\right)\right\} \\
& P_{t}^{c u t}=\sum\left\{\min \left(0,\left(P_{t}-P_{t-1}\right)\right\}\right. \\
& P_{t}^{r e c}=\sum\left\{\max \left(0,\left(P_{t}-P_{t-1}\right)-\left(P_{t}^{\max }-P_{t-1}^{\max }\right)\right\}\right.
\end{aligned}
$$

Substituting the decomposed price variable given in Eq. (2) into Eq. (1) gives a generalized equation as follows:

6. Nevertheless, we estimate both fixed effects and random effects, and carry out a Hausman test to select the specification that better suits our dataset. 


$$
\begin{aligned}
E I_{i t}= & \beta_{m} P_{i t}^{\max }+\beta_{c} P_{i t}^{c u t}+\beta_{r} P_{i t}^{r e c}+\beta_{m 1} P_{i t}^{\max } * P A T_{i t}+\beta_{c 1} P_{i t}^{c u t}+\beta_{r 1} P_{i t}^{r e c} * P A T_{i t}+ \\
& +\beta^{\prime} X_{i t}+\delta_{i} D_{t}+\alpha_{i}+\varepsilon_{i t}
\end{aligned}
$$

where $E I_{i t}$ is the logarithm of the energy intensity for each subsector at time $t, P_{i t}^{\max }$ is the logarithm of real price maximum for each subsector, $P_{i t}^{\text {rec }}$ is the logarithm of real price recovery for each subsector while $P_{i t}^{c u t}$ is the logarithm of real price cut for each subsector. $P_{i t}^{\max } * P A T_{i t}$ is the interaction term between patent stock and the energy price maximum, $P_{i t}^{r e c} * P A T_{i t}$ is the interaction term between patent stock and energy price recovery and $P_{i t}^{c u t} * P A T_{i t}$ is the interaction term between patent stock and energy price cut. $X_{i t}$ are other covariates discussed in Eq. (1) above, while $D_{t}, \alpha_{i}$ and $\varepsilon_{i t}$ also remain as defined in Eq. (1).

\section{DATA SOURCE AND DESCRIPTIVE STATISTICS}

Our analysis is based on panel data from 12 manufacturing subsectors at the two-digit level using the International Standard of Industrial Classification (ISIC) Rev 3 for 17 European countries over the period 1995-2009. The selection of the 17 countries in our sample is determined mainly by data availability, especially by data on our main variable of interest, industry-level gross energy use and patent data. ${ }^{7}$ Together, these countries account for over $80 \%$ of EU gross value added. The manufacturing subsectors covered by our study are reported in Table A1 in the Appendix, which shows the ISIC rev3 classification of the industries. The data series for industry-specific gross value added, capital stock, labor, price deflators, gross energy use and energy expenditure are obtained from the World Input-Output Database (WIOD). ${ }^{8}$ The WIOD gives a comprehensive summary of all transactions in the global economy between industries (and final users) across countries over the years covered by the database (1995 to 2009). ${ }^{9}$ It is based on national accounts data harmonized for international comparability. Amongst others, it reports (direct) energy costs, output, value added and other environmental indicators like energy use, CO2 emission etc. According to Voigt et al (2014), the WIOD offers some advantages in that the harmonization procedures undertaken throughout the data collection minimize the risks of measurement errors. Also, the consistence in data collection and comparability across countries describes the data efficiency gains at the sectoral and global levels. Besides the broad country coverage and sectoral disaggregation, the dataset has another key advantage as it contains several unified satellite accounts with the same sectoral classification as the core dataset.

We measure energy intensity by the ratio of energy use input to output. The indicator of output is gross value added, expressed in millions of national currencies at current prices, and extracted from the Socio-Economic Accounts section of the WIOD. To generate the real output, the gross value added is deflated using the subsector price index of gross value added (where $1995=$ 100). ${ }^{10}$ To ensure international comparisons, the real output in national currencies are then converted

7. The 17 EU countries consider in the study are Austria, Belgium, Denmark, Finland, France, Germany, Greece, Hungary, Ireland, Italy, Luxembourg, Netherland, Poland, Portugal, Spain, Sweden and United Kingdom.

8. See Timmer et al., (2015) for a detailed discussion on the methodology used in the World Input-Output Database.

9. Due to lack of extended data for the industry-level energy use in WIOD, the analysis was confined to a fifteen-year sample period, spanning 1995-2009. Recent empirical studies that faced similar constraint having employed data from WIOD, covering the 15-year time period (1995-2009), including: Hübler and Glas (2014), Löschel et al. (2015), Adetutu et al., (2016) and Sharimakin et al.(2018).

10. The WIOD provides data on sectoral price deflators, allowing us to retain important information and variations with respect to price development, which is an advantage over the use of aggregate national price deflators in sectoral analysis (Voigt et al, 2014). 
to international prices (US\$) using the purchasing power parity exchange rates from the Penn World Table (PWT7.1). Gross energy use, which is measured in physical units (TJ), is extracted from the Environmental Accounts section of the WIOD. We also capture the share of gas and electricity as the fraction of the sum of gas and electricity in gross energy use. The amount of gas and electricity in physical units (TJ) are also extracted from the WIOD. Capital intensity is expressed as a ratio of capital to labor. One of the advantages of the WIOD is the availability of a capital stock variable. It is often difficult to obtain (physical) capital stock data from official data sources, not least at the industrial level. The WIOD offers information about real fixed capital stocks and gross fixed capital formation for each country and sector. Real fixed capital stock is measured in 1995 prices and converted to million 1995 international dollars in a manner analogous to output. Labor is measured as number of people engaged in work (in thousands). We use this information to construct a measure of capital intensity expressed as capital-labor ratio.

In the case of energy prices, previous studies (e.g. Sato and Dechezleprêtre, 2015; Parker and Liddle, 2016) have relied on country-level industrial energy prices published by the US Energy Information Agency (EIA). However, these series are aggregate country-level industrial energy prices data which do not reveal sufficient information about sector-specific details. Therefore, we follow Adetutu et al., (2016) and Sharimakin et al., (2018) to generate industry-specific real prices of energy based on the ratio of energy input expenditure at constant prices in US\$ to gross energy use (in TJ). This approach provides a more robust measure of industrial energy prices faced by each industry. ${ }^{11}$ The intermediate energy input expenditure is also obtained from WIOD and then deflated to constant $(1995=100)$ prices by applying the implicit price deflator for each subsector. The constant price series are then converted to international prices using the purchasing power parity exchange rates from the Penn World Table (PWT7.1).

In our study, we define manufacturing innovation following the definition of Abernathy and Utterback (1978) as "any product or process new to a business unit (firm)." Hence, we use patents as a reflection of actual innovative activity in a given year. ${ }^{12}$ Patents have been commonly used as an output-based measure of technological innovation. Past studies have also lent credence to the superiority of patents to R\&D as a potential proxy for innovation (see Popp, 2001, 2006; Ulku, 2007; Johnstone et al., 2010; Aghion et al., 2012). The Patent variable include all patents granted by the European Patent Office (EPO) over the study period. Patents granted are linked to industrial sectors using a concordance table between industries and technologies made available by the Fraunhofer Institute for System and Innovation Research. ${ }^{13}$ Instead of using patent flows as a measure of innovation, we constructed patent stocks for each industry following an approach proposed by Heeley et al (2000), which confines the depreciation of the patent stock to a period lasting only several years. The approach also addresses the problem of calculating initial patent stock in the perpetual inventory approach. Similar to Blind and Jungmittag (2008), we assume a deprecation rate of 15\% for the calculation of patent stocks and compute patent stocks as follows;

$$
P_{i t}=\sum_{r=t-5}^{t}(1-\mu)^{(t-\tau)} P_{i t}^{g r}
$$

11. We also use alternative measures of energy price including the Brent oil price (Tables A8-A11) and country-specific industrial energy prices (Tables A12-A15) to test for the robustness of our preferred measure.

12. For our Patent variable, we use quantity of patents granted in a year. Like other flow variables, such as expenditure and investment, it is in reference to a specific time.

13. We are grateful to Dr Peter Neuhäusler of the Fraunhofer Institute for Systems and Innovation Research ISI in Karlsruhe, Germany, for providing industry-level patent data. See Van Looy et al. (2014) for a format of patent statistics concordance. 
where $P_{i t}^{g r}$ is the number of EPO patent granted to a given EU member state in subsector $i$ in year $t, \mu$ is the depreciation rate and $\tau$ is $t-5$. We interact patent stock with energy price in order to investigate the sectorial technological response to an increase in energy prices. We hypothesize that higher energy prices lead to the development of more energy-saving technologies which incidentally increase innovative activities.

Trade openness for each subsector is measured as the ratio of the sum of imports and exports to output. Data for subsector exports and imports are accessed from the Structural Analysis database of the OECD. Exports and imports are available in millions of local currency units from WIOD and deflated using base year 1995 sector-specific implicit gross domestic deflators taken from the same database. The constant (real) local currency units were then converted to 1995 international dollars using purchasing power parity conversion from Penn World Tables. We also control for output growth, which is measured as the rate of change of value-added of each sub-sector using value-added data extracted from the WIOD. Although the convention in energy demand studies is to use GDP as a measure of income, considering that our study is on disaggregated industrial energy intensity, we adopt the approach by Zheng et al (2011), and use growth rate of gross value added which controls for the effect of structural changes in each subsector as opposed to level of gross value added, an equivalent of GDP in residential and country-level studies. ${ }^{14}$ Growth rate of value-added accounts for manufacturing output expansion in each subsector. We also control for carbon taxation using data obtained from Dolphin et al. (2018), which in turn was compiled from various sources.

Table 1 shows summary statistics for the levels of the key variables in 1995 for each country and Panel B presents the same for the changes through 2009. The ranking of countries looks sensible with the Germany having the highest patent stock (2080), followed by France (893) and the UK (500). All countries have experienced significant investment in technological innovations as indicated by the growth in the patent stock in column (4) of Panel B, with the exception being the UK, which experienced negative change. On average, the patent stock increased from 279 in 1995 to 345 in 2009 . Germany had the fastest absolute change in the patent stock, increasing by 682 . Poland had the most energy-intensive economy, but saw the largest efficiency improvement between 1995-2009 via a reduction in energy intensity by over 57\%. The mean energy intensity decreased by $8.4 \%$ from $12.7 \%$ in 1995 to $11.02 \%$ in 2009 . Hungary, Spain and Portugal witnessed an increase in energy intensity growth between 1995 and 2009. Table A3 in the Appendix also shows similar cross-industry levels and growth in key variables.

\section{RESULTS AND DISCUSSIONS}

The estimation models specified in equations (1) and (2) are reported in Tables 2 to 6 for industrial energy intensity. We model both price symmetric and asymmetric response of energy intensity to energy prices. We estimate random effects and fixed-effects estimators to avoid the potential bias associated with the pooled OLS due to the presence of unobservable sector-specific characteristics associated with panel data. In order to choose between the RE and FE estimators, we conducted a Hausman (1978) test. The test statistic is based upon contrasting the FE and RE estimators in which the standard Hausman test rejects the null hypothesis that the conditional mean of the disturbances given the regressors is zero. Based on the statistical power of the test, the Hausman test

14. So far, Zheng et al (2011) remains the only available industry-level study on aggregate energy intensity which does not decompose energy intensity into efficiency change and structural change. 
Table 1: Summary Statistics by Country

\begin{tabular}{|c|c|c|c|c|c|c|}
\hline \multirow[b]{2}{*}{ Country } & \multicolumn{6}{|c|}{ A: 1995 Levels Averaged by Country } \\
\hline & $\begin{array}{l}\text { Energy } \\
\text { Intensity } \\
\text { (TJ/\$M PPP) }\end{array}$ & $\begin{array}{l}\text { In (Value } \\
\text { Added) } \\
\text { (\$M PPP) }\end{array}$ & $\begin{array}{l}\text { Total } \\
\text { Price } \\
\text { (\$M PPP/TJ) }\end{array}$ & $\begin{array}{l}\text { Patent } \\
\text { Stock } \\
\text { (Number) }\end{array}$ & $\begin{array}{l}\text { Trade } \\
\text { Openness } \\
\text { (ratio) } \\
\end{array}$ & $\begin{array}{l}\text { Share } \\
\text { Gas \& Electric } \\
\text { (ratio) }\end{array}$ \\
\hline Austria & 11.297 & 7.677 & 0.009 & 108.893 & 4.191 & 0.608 \\
\hline Belgium & 12.216 & 7.773 & 0.012 & 94.472 & 7.016 & 0.552 \\
\hline Denmark & 8.775 & 6.903 & 0.004 & 65.890 & 6.011 & 0.537 \\
\hline Finland & 21.258 & 7.078 & 0.006 & 93.807 & 3.117 & 0.315 \\
\hline France & 13.142 & 9.219 & 0.014 & 893.734 & 3.100 & 0.614 \\
\hline Germany & 9.581 & 10.015 & 0.010 & 2080.386 & 2.666 & 0.563 \\
\hline Greece & 11.272 & 6.801 & 0.015 & 1.627 & 2.532 & 0.285 \\
\hline Hungary & 14.264 & 6.968 & 0.021 & 3.993 & 1.575 & 0.618 \\
\hline Ireland & 8.069 & 6.614 & 0.018 & 11.351 & 4.285 & 0.536 \\
\hline Italy & 9.103 & 9.735 & 0.015 & 290.701 & 1.622 & 0.654 \\
\hline Luxembourg & 12.423 & 4.738 & 0.007 & 13.348 & 0.000 & 0.645 \\
\hline Netherlands & 15.604 & 7.966 & 0.011 & 363.801 & 6.201 & 0.677 \\
\hline Poland & 22.381 & 8.153 & 0.011 & 0.555 & 0.891 & 0.243 \\
\hline Portugal & 13.096 & 7.267 & 0.011 & 0.592 & 3.141 & 0.301 \\
\hline Spain & 9.014 & 8.993 & 0.016 & 31.836 & 2.457 & 0.481 \\
\hline Sweden & 16.389 & 7.506 & 0.005 & 187.946 & 4.462 & 0.420 \\
\hline UK & 8.011 & 9.473 & 0.010 & 500.684 & 1.419 & 0.583 \\
\hline \multirow[t]{3}{*}{ Mean } & 12.701 & 7.832 & 0.011 & 279.036 & 3.233 & 0.507 \\
\hline & \multicolumn{6}{|c|}{ B: Changes from 1995 to 2009 Averaged by Country } \\
\hline & $\begin{array}{l}\Delta \text { (Energy } \\
\text { Intensity) } \\
(\mathrm{TJ} / \mathbf{S M} \mathrm{PPP})\end{array}$ & $\begin{array}{l}\Delta \text { In (Value } \\
\text { Added) } \\
\text { (\$M PPP) }\end{array}$ & $\begin{array}{l}\Delta \text { (Total } \\
\text { Price) } \\
\text { (\$MPPP/TJ) }\end{array}$ & $\begin{array}{l}\Delta \text { (Patent } \\
\text { Stock) } \\
\text { (Number) }\end{array}$ & $\begin{array}{l}\Delta(\text { Trade } \\
\text { Openness) } \\
\text { (ratio) }\end{array}$ & $\begin{array}{l}\Delta(\text { Share } \\
\text { Gas \& Electric) } \\
\text { (ratio) }\end{array}$ \\
\hline Austria & -2.532 & 0.257 & 0.006 & 41.523 & 1.786 & 0.034 \\
\hline Belgium & -2.463 & 0.094 & 0.008 & 34.165 & 10.028 & 0.063 \\
\hline Denmark & -1.976 & -0.240 & 0.006 & 23.701 & 21.252 & 0.062 \\
\hline Finland & -7.018 & 0.301 & 0.006 & 29.211 & 1.421 & 0.106 \\
\hline France & -5.769 & 0.337 & 0.014 & 80.976 & -3.100 & 0.013 \\
\hline Germany & -1.918 & 0.083 & 0.019 & 682.715 & 1.787 & 0.041 \\
\hline Greece & -1.385 & 0.032 & 0.009 & 4.992 & 1.643 & 0.144 \\
\hline Hungary & 16.594 & -0.491 & -0.001 & 3.254 & 2.991 & -0.063 \\
\hline Ireland & -0.696 & 0.344 & 0.002 & 15.899 & 1.889 & -0.024 \\
\hline Italy & -0.299 & -0.224 & 0.008 & 196.044 & 0.940 & -0.004 \\
\hline Luxembourg & -1.934 & 0.337 & 0.008 & 20.004 & 20.847 & -0.107 \\
\hline Netherlands & -3.243 & 0.083 & 0.010 & 7.950 & 6.550 & -0.009 \\
\hline Poland & -12.792 & 0.471 & 0.016 & 9.688 & -0.891 & 0.172 \\
\hline Portugal & 0.242 & 0.107 & 0.004 & 4.511 & -3.141 & 0.226 \\
\hline Spain & 2.559 & -0.057 & 0.001 & 55.722 & -1.159 & 0.148 \\
\hline Sweden & -5.554 & 0.342 & 0.020 & 90.109 & 1.303 & 0.075 \\
\hline UK & -0.7285 & -0.133 & 0.005 & -117.767 & 0.381 & 0.031 \\
\hline Mean & -1.680 & 0.094 & 0.008 & 69.570 & 3.724 & 0.054 \\
\hline
\end{tabular}

suggests that fixed effects estimates are consistent. On this basis, we choose a fixed effects model as the appropriate model for our data and our subsequent analysis and discussions are premised on the estimates of fixed effects in column (3) and (4) as reported in Table 2 and are used throughout the remainder of our study.

In column (3), as expected, energy price has a negative and statistically significant relationship with industrial energy intensity. Holding everything else constant, the elasticity of -0.61 implies that a $1 \%$ higher energy price is associated with a $0.61 \%$ decline in energy intensity. In addition, energy price is highly significant for the three price components in the asymmetric energy price specification (column 4). The asymmetric energy price model provides some insight into the varying magnitude of the impact of shifting energy prices. Energy price maximum has the highest 
Table 2: Estimation Results for EU Manufacturing Sector

\begin{tabular}{|c|c|c|c|c|}
\hline Variables & $\begin{array}{l}\text { (1) } \\
\text { Random effects model }\end{array}$ & $\begin{array}{l}\text { (2) } \\
\text { Random effects model }\end{array}$ & $\begin{array}{l}(3) \\
\text { Fixed effects model }\end{array}$ & $\begin{array}{l}\text { (4) } \\
\text { Fixed effects model }\end{array}$ \\
\hline Total Price & $\begin{array}{l}-0.614 * * * \\
(0.0241)\end{array}$ & & $\begin{array}{l}-0.607 * * * \\
(0.0237)\end{array}$ & \\
\hline Price-max & & $\begin{array}{l}-0.660 * * * \\
(0.0295)\end{array}$ & & $\begin{array}{l}-0.737 * * * \\
(0.0309)\end{array}$ \\
\hline Price-cut & & $\begin{array}{l}-0.488 * * * \\
(0.0403)\end{array}$ & & $\begin{array}{l}-0.465 * * * \\
(0.0382)\end{array}$ \\
\hline Price-rec & & $\begin{array}{l}-0.668^{* * * *} \\
(0.0316)\end{array}$ & & $\begin{array}{l}-0.620 * * * \\
(0.0343)\end{array}$ \\
\hline Patent & $\begin{array}{l}-0.174 * * * \\
(0.0282)\end{array}$ & $\begin{array}{l}-0.0279 * * \\
(0.0134)\end{array}$ & $\begin{array}{l}-0.120 * * * \\
(0.0304)\end{array}$ & $\begin{array}{l}-0.0126 \\
(0.0145)\end{array}$ \\
\hline Openness & $\begin{array}{l}0.0940 * * * \\
(0.0238)\end{array}$ & $\begin{array}{l}0.0955^{* * *} \\
(0.0259)\end{array}$ & $\begin{array}{l}0.244 * * * \\
(0.0264)\end{array}$ & $\begin{array}{l}0.206 * * * \\
(0.0267)\end{array}$ \\
\hline Growth-VA & $\begin{array}{l}-0.389 * * * \\
(0.0472)\end{array}$ & $\begin{array}{l}-0.414 * * * \\
(0.0468)\end{array}$ & $\begin{array}{l}-0.355^{* * * *} \\
(0.0453)\end{array}$ & $\begin{array}{l}-0.397 * * * \\
(0.0441)\end{array}$ \\
\hline Capital-intensity & $\begin{array}{l}0.0804 * * * \\
(0.0305)\end{array}$ & $\begin{array}{l}0.0726 * * \\
(0.0324)\end{array}$ & $\begin{array}{l}-0.00803 \\
(0.0333)\end{array}$ & $\begin{array}{l}-0.0127 \\
(0.0326)\end{array}$ \\
\hline Share-gas-electric & $\begin{array}{l}-0.321 * * * \\
(0.0505)\end{array}$ & $\begin{array}{l}-0.394 * * * \\
(0.0504)\end{array}$ & $\begin{array}{l}-0.298 * * * \\
(0.0495)\end{array}$ & $\begin{array}{l}-0.322 * * * \\
(0.0482)\end{array}$ \\
\hline Patent*price & $\begin{array}{l}-0.0286 * * * \\
(0.00518)\end{array}$ & & $\begin{array}{l}-0.0212 * * * \\
(0.00515)\end{array}$ & \\
\hline Patent*price-max & & $\begin{array}{l}-0.0333 * * * \\
(0.00587)\end{array}$ & & $\begin{array}{l}-0.0231 * * * \\
(0.00573)\end{array}$ \\
\hline Patent*price-cut & & $\begin{array}{l}0.00696 \\
(0.0105)\end{array}$ & & $\begin{array}{l}0.00546 \\
(0.0101)\end{array}$ \\
\hline Patent*price-rec & & $\begin{array}{l}-0.0225 * * * \\
(0.00675)\end{array}$ & & $\begin{array}{l}-0.0146 * * \\
(0.00660)\end{array}$ \\
\hline Constant & $\begin{array}{l}-2.274 * * * \\
(0.392)\end{array}$ & $\begin{array}{l}0.959 * * \\
(0.408)\end{array}$ & $\begin{array}{l}-4.268 * * * \\
(0.433)\end{array}$ & $\begin{array}{l}-0.611 \\
(0.423)\end{array}$ \\
\hline $\begin{array}{l}\text { Observations } \\
\text { R-sured }\end{array}$ & 2,197 & 2,197 & 2,197 & $\begin{array}{l}2,197 \\
0,660\end{array}$ \\
\hline $\begin{array}{l}\text { R-squared } \\
\text { Year DVs }\end{array}$ & Yes & Yes & $\begin{array}{l}0.637 \\
\text { Yes }\end{array}$ & $\begin{array}{l}0.660 \\
\text { Yes }\end{array}$ \\
\hline Industry Effects & Yes & Yes & Yes & Yes \\
\hline Country Effects & Yes & Yes & Yes & Yes \\
\hline
\end{tabular}

Standard errors in parentheses, $* * * \mathrm{p}<0.01, * * \mathrm{p}<0.05, * \mathrm{p}<0.1$

statistically significant impact on energy intensity with a price elasticity of -0.74 , followed by price recovery, -0.62 , while energy price cut, -0.47 , experiences the lowest impact of the three asymmetric price components. These findings indicate that the pattern of price movements is crucial in stimulating efficiency improvement as price rises led to more efficiency improvements than when efficiency gains when prices are low. These results are consistent with Lescaroux (2008) who provides a related evidence of asymmetric response of efficiency to energy prices in the US manufacturing sector but contrasts with those of Parker and Liddle (2016). In tandem with the first hypothesis, $H 1$, energy price remains the major determinant of energy intensity in EU manufacturing sectors.

Likewise, the impact of the patent stock is negative and statistically significant, same as the interaction between the energy price and patent stock. Our results are consistent with the findings reported by Fisher-Vanden et al. (2016) for four Chinese energy-intensive industries. Reduction in energy intensity is driven by patent stock through two key influences: (i) efficiency improvement due to technological innovations which is independent of the level of energy prices and (ii) technological innovation induced by raising energy prices. The second hypothesis is also confirmed by our findings, which reveal that patent stock seems to consistently lead to a reduction in overall industrial energy intensity. Confirming the second hypotheses, $H 2: 1$ and $H 2: 2$, technological innovation (as proxied by patent stock) is consistently associated with a decline in manufacturing energy intensity. 
The technological innovation induced by rising energy prices, as measured by the patent and price interaction, also results in substantial reductions in manufacturing energy intensity.

The patent stock coefficient has the expected negative sign and is robust in the symmetric price model, although it is insignificant in the asymmetric price model. Furthermore, the statistically significant coefficients of the interaction terms between patent and asymmetric price components indicates a greater reduction in energy intensity at the maximum energy price level, potentially due to adoption of more energy-efficient substitutes and technological innovation. By contrast, the interaction term shows no significant impact on energy intensity at low prices as there is less incentive for process innovation in order to reduce energy use when energy prices are low. These findings are not surprising given the short panel framework of our data coupled with the relatively persistent growth in energy price over the sample period. In congruity with the second set of hypotheses, we find that the decline in energy intensity is much more sensitive to changes in maximum price than in price cut, which provides evidence of an asymmetric response of efficiency to energy prices in which rising prices between 2004 and 2008 result in greater efficiency improvements than when prices fall.

The impact of value-added growth rate on energy intensity is negative and robust across the model specifications. In line with other studies (e.g., Jimenez and Mercado, 2014), our finding suggests that an increase in output level using the same level of current inputs tends to enhance efficiency change. Although not quite robust, the result also shows that the coefficient of capital intensity is negatively associated with energy intensity. This implies that as stock of capital increases due to accumulation of more energy efficient capital stock in relation to labour, energy intensity tends to decrease. Juxtaposing our finding with the third hypothesis, $H 3$, we could not validate the hypothesis as capital intensity does not seem to have any significant impact on energy intensity. Conversely, the result also shows that increases in international trade appears to raise energy intensity in the EU manufacturing sector. Although trade openness is generally believed to contribute to declining energy intensity in the EU owing to potential spillover effects as set out in the fourth hypothesis, $H 4$, our analysis indicates that energy intensity rises substantially with increased trade openness in the manufacturing sector. Zhang (2013) finds a similar result that energy intensity slightly increases with the increase in trade openness for the Eastern Europe transition economies manufacturing sector. One reason adduced to the finding of positive relationship of trade openness and energy intensity stems from the supposition that trade induces specialization in more energy-intensive industries. Also, the impact of state aids by EU member countries reinforces support for international competitiveness of these specialized trade exposed energy-intensive sectors. We will expect that the higher the share of gas and electricity in the total energy use, the greater the corporate pressure to reduce prices. ${ }^{15}$ Calel and Dechezleprêtre (2016) report that fuel switching, shifting the fuel mix away from coal in favor of natural gas, has been responsible for the major share of the reduction in carbon dioxide emissions since the EU ETS was instituted in 2005. Overall, the estimates in Table 2 confirm that energy prices in general do play a crucial role in reducing energy intensity. It also reflects a pattern consistent with the notion that rising energy prices could directly engender reduced energy intensity as well as the indirect effect of stimulating energy-saving technology development and adoption.

Focusing on Table 3, we account for sectoral heterogeneities on the assumption that factors will affect industries differently owing to their variation in energy intensity and exposure to the Emission Trading Directive and other emission reduction obligations, such as carbon or energy taxes. To explore these heterogeneities, we first split our sample into two subsamples i.e. energy-intensive and non-energy intensive industries. Building on existing literature (see Liddle, 2012; Sato

15. We expect different sectors to have different fuel mix given that different fuel mix drive responses such as investment. The reason we have to control fuel mix as well as heterogeneity.

Open Access Article 
and Dechezleprêtre, 2015; Song and Oh, 2015), we consider four energy-intensive industries: paper (ISIC 21-22), chemicals (ISIC 24), non-metallic products (ISIC 25 23), basic and fabricated metal (ISIC 27-28). The other eight industries are categorized as less-energy intensive manufacturing industries. The immediate striking difference between the fixed effects estimates of the energy-intensive and less energy-intensive sectors lies in the statistical significance of patent stock in both fixed effect models of energy-intensive industries as opposed to less-energy intensive industries where the patent stock coefficient is not statistically different from zero. The larger coefficients for the patent stock of the energy-intensive industries suggests that heavy industries rely more on innovation to reduce energy intensity compared with light industries. This finding further reinforces the second hypothesis, H2.1, since we would expect energy-intensive industries to generate more innovation, thereby leading to a greater reduction energy intensity within these firms.

Table 3: Estimation Results for Manufacturing Sector Groups

\begin{tabular}{|c|c|c|c|c|}
\hline \multirow[b]{2}{*}{ Variables } & \multicolumn{2}{|c|}{ Energy-intensive industries } & \multicolumn{2}{|c|}{ Less Energy-intensive industries } \\
\hline & Fixed effects & Fixed effects & Fixed effects & Fixed effects \\
\hline Total Price & $\begin{array}{l}-0.502 * * * \\
(0.0343)\end{array}$ & & $\begin{array}{l}-0.669 * * * \\
(0.0318)\end{array}$ & \\
\hline Price-max & & $\begin{array}{l}-0.675 * * * \\
(0.0573)\end{array}$ & & $\begin{array}{l}-0.855^{* * * *} \\
(0.0393)\end{array}$ \\
\hline Price-cut & & $\begin{array}{l}-0.415^{* * *} \\
(0.0641)\end{array}$ & & $\begin{array}{l}-0.499 * * * \\
(0.0482)\end{array}$ \\
\hline Price-rec & & $\begin{array}{l}-0.0856 \\
(0.0857)\end{array}$ & & $\begin{array}{l}-0.704 * * * \\
(0.0426)\end{array}$ \\
\hline Patent & $\begin{array}{l}-0.138^{* *} \\
(0.0542)\end{array}$ & $\begin{array}{l}-0.0921^{* * *} \\
(0.0216)\end{array}$ & $\begin{array}{l}-0.0848 * * \\
(0.0375)\end{array}$ & $\begin{array}{l}0.0249 \\
(0.0197)\end{array}$ \\
\hline Openness & $\begin{array}{l}0.301 * * * \\
(0.0380)\end{array}$ & $\begin{array}{l}0.338 * * * \\
(0.0375)\end{array}$ & $\begin{array}{l}0.208 * * * \\
(0.0349)\end{array}$ & $\begin{array}{l}0.142 * * * \\
(0.0356)\end{array}$ \\
\hline Growth-VA & $\begin{array}{l}-0.229 * * * \\
(0.0686)\end{array}$ & $\begin{array}{l}-0.285^{* * *} \\
(0.0664)\end{array}$ & $\begin{array}{l}-0.374 * * * \\
(0.0578)\end{array}$ & $\begin{array}{l}-0.419 * * * \\
(0.0557)\end{array}$ \\
\hline Capital-intensity & $\begin{array}{l}0.0162 \\
(0.0485)\end{array}$ & $\begin{array}{l}0.0386 \\
(0.0470)\end{array}$ & $\begin{array}{l}-0.0245 \\
(0.0435)\end{array}$ & $\begin{array}{l}-0.0492 \\
(0.0428)\end{array}$ \\
\hline Share-gas-electric & $\begin{array}{l}-0.452 * * * \\
(0.0706)\end{array}$ & $\begin{array}{l}-0.482 * * * \\
(0.0684)\end{array}$ & $\begin{array}{l}-0.191 * * * \\
(0.0646)\end{array}$ & $\begin{array}{l}-0.227 * * * \\
(0.0622)\end{array}$ \\
\hline Patent*price & $\begin{array}{l}-0.0141^{*} \\
(0.00817)\end{array}$ & & $\begin{array}{l}-0.0215 * * * \\
(0.00676)\end{array}$ & \\
\hline Patent*price-max & & $\begin{array}{l}0.00385 \\
(0.0130)\end{array}$ & & $\begin{array}{l}-0.0176^{* *} \\
(0.00705)\end{array}$ \\
\hline Patent*price-cut & & $\begin{array}{l}0.00520 \\
(0.0178)\end{array}$ & & $\begin{array}{l}0.00728 \\
(0.0125)\end{array}$ \\
\hline Patent*price-rec & & $\begin{array}{l}-0.0861^{* * * *} \\
(0.0221)\end{array}$ & & $\begin{array}{l}-0.0101 \\
(0.00823)\end{array}$ \\
\hline Constant & $\begin{array}{l}-3.746 * * * \\
(0.640)\end{array}$ & $\begin{array}{l}-1.469 * * \\
(0.592)\end{array}$ & $\begin{array}{l}-4.488 * * * \\
(0.565)\end{array}$ & $\begin{array}{l}-0.325 \\
(0.561)\end{array}$ \\
\hline Observations & 785 & 785 & 1,412 & 1,412 \\
\hline R-squared & 0.628 & 0.657 & 0.660 & 0.689 \\
\hline Year DVs & Yes & Yes & Yes & Yes \\
\hline Industry Effects & Yes & Yes & Yes & Yes \\
\hline Country Effects & Yes & Yes & Yes & Yes \\
\hline
\end{tabular}

Standard errors in parentheses, $* * * \mathrm{p}<0.01, * * \mathrm{p}<0.05, * \mathrm{p}<0.1$

Energy price elasticities remain negative across the models and statistically significant for both industries, with less-intensive industries responding more to price increases than energy-intensive industries. Given the relative price sensitivity of the less energy-intensive industries, price increases account for more induced technological innovation in lighter manufacturing industries compared to energy-intensive industries. One possible explanation is that in less energy-intensive 
industries' investments in energy-efficient technologies are driven largely by energy prices, while policies related to environmental concerns could be responsible for the propensity for innovation in energy-intensive industries. This finding implies that price elasticities of energy-intensive industries are more inelastic than those of less energy-intensive industries. Similar to the price decomposition estimates of the manufacturing industries reported in Table 2, the magnitude of the impact of price is seen to be highest at the maximum price level, followed by price-recovery while price-cut has the lowest price impact on energy intensity.

More often than not, industrial energy policies across different European countries are tailored to meet country-specific industrial strategies. For instance, in order to reduce $\mathrm{CO} 2$ emissions, countries like Denmark, Finland, Sweden and Poland have unilaterally adopted of carbon tax dating back to the early 1990s. ${ }^{16}$ A carbon tax policy is aimed at promoting substitution of fuel products and thereby encouraging energy saving as well as investment in energy efficiency improvement. Even for an EU-wide mechanism such as the ETS, in Phases I and II of the scheme (2005-7 and 2008-12), countries were allowed to set the allocation of individual allowances, allowing for considerable differences to arise. These inter-regional differences in climate change and energy policy will undoubtedly have an impact on regional energy consumption and regional energy intensity. Therefore, one way to possibly gain a more intuitive insight into geographical variation in energy intensity of European countries is through regional analysis. We cluster the 17 countries into four regions (Western Europe, Southern Europe, Eastern Europe and Northern Europe) to analyse any regional patterns while controlling for carbon tax. ${ }^{17}$

No carbon tax estimate is reported in Table 4 for the other three regions as none of the countries in these regions introduced an effective carbon tax during the sample period. ${ }^{18}$ Interestingly, the results show a negative and robust relationship between carbon tax and energy intensity in Northern Europe. Specifically, the carbon tax estimates of approximately -0.13 and -0.14 in both fixed effects models respectively for Northern Europe suggest that 1\% increase in carbon tax will result in energy intensity reduction by $0.13 \%$ and $0.14 \%$ respectively. The findings affirm the fifth hypothesis, H5.1, as we expect that there would be a clear negative relationship between the level of the carbon tax and energy intensity in those countries where a carbon tax has been imposed.

The comparison of the patent coefficients suggests a negative and statistically significant relationship with energy intensity across models in Northern and Southern Europe. The magnitude of the parameter estimates for the patent stock for Northern Europe is almost twice as large as the estimates of Southern Europe, possibly due to the existence of carbon tax which provides an incentive for induced innovation towards technologies to reduce emissions. A similar patent effect can be observed in Eastern Europe in the symmetric price model. Invariably, this underscores the assumption that policies on environment concerns and regulations are the major conservation strategies of promoting technological innovation development in manufacturing sector. The picture is less clearcut for both Western and Eastern Europe as the patent estimates have conflicting signs (although it is not significant for the price symmetric model in Western Europe).

16. The Nordic countries were the first countries to levy carbon taxes. Finland imposed a carbon tax in 1990; Norway and Sweden in 1991; and Denmark in 1992. Poland also imposed a carbon tax in 1990, which was (and remained) much lower than those in the Nordic countries (World Bank et al., 2016).

17. See Table A2 in the Appendix for the regional classification of the 17 sample countries.

18. Technically, as Zylicz (2013) explains, Poland does have a very small carbon tax of 0.24 PLN/t (0.06 euro/t) - roughly $1 \%$ of EU-ETS prices, which is well below the Pigouvian level understood as the level necessary to undertake the abatement at the socially justified (efficient) scale. Different countries in the three regions also had a range of other measures, for example, the UK created a 'Climate Change Levy', but this applied to all central generating plants and included nuclear power, which does not emit $\mathrm{CO} 2$. 


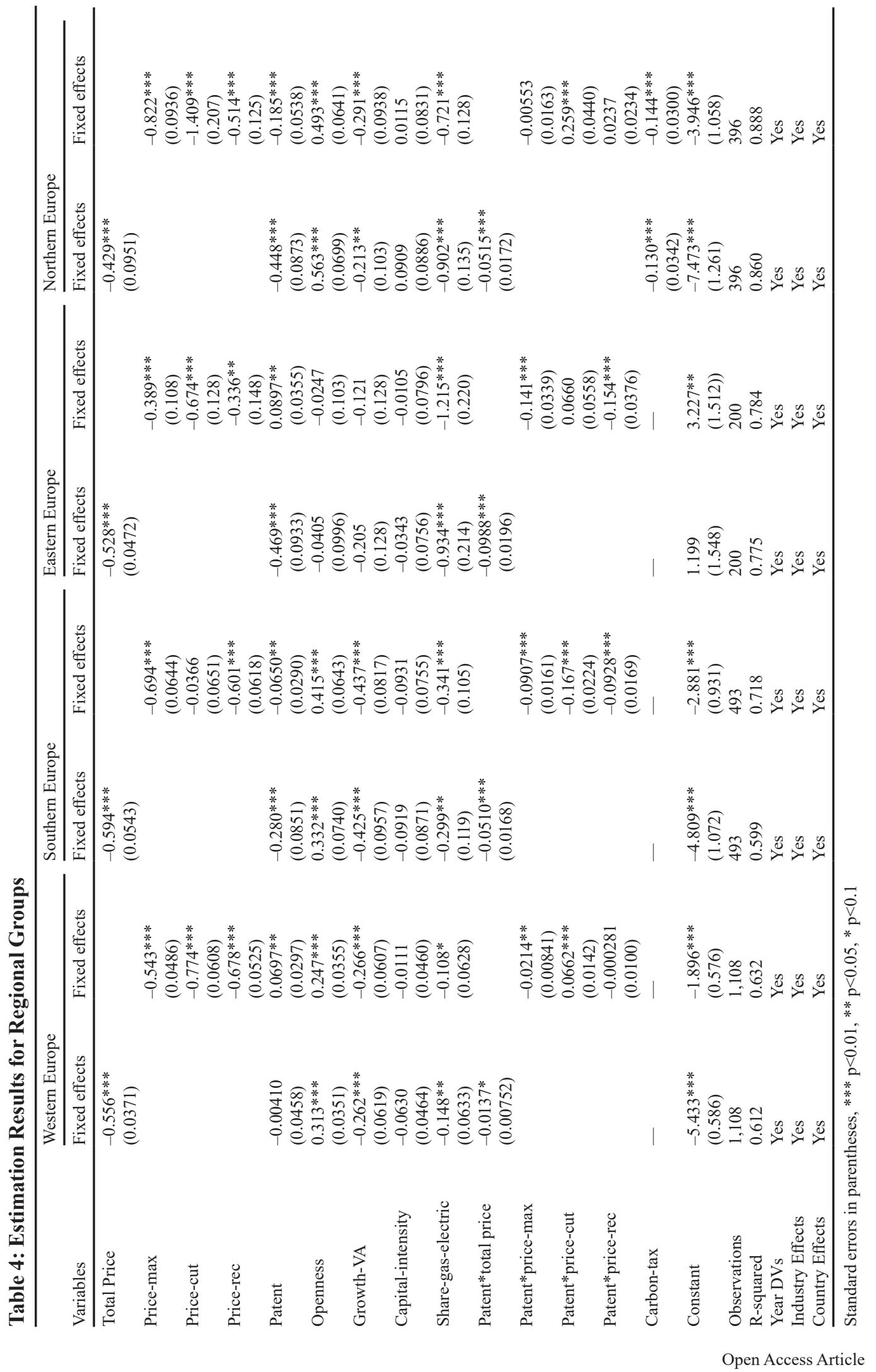


The coefficient of total energy price is negative and significantly affects energy intensity in all the groups as expected. We observe fairly large responses of energy intensity to price changes across each region, with Northern Europe having the lowest price effect on energy intensity in the price symmetric model. Compared with average price for the EU manufacturing sector, price elasticities for individual regions is lower than price elasticity of the full sample.

The absence of a carbon tax that could encourage energy efficiency improvement in Western and Southern Europe indirectly feeds into the energy price estimates as it can be observed that the magnitudes of price elasticities are slightly larger than in other regions. Moreover, it is not surprising that trade openness continues to have the same positive and robust effect on manufacturing sector energy intensity. Although in separating the data into four regions, we might have expected that net exporting regions with a positive trade balance might behave differently from other regions, but the results show otherwise. Hence, the findings do not change in the face of regional heterogeneities. By contrast, trade openness seems to show a negative relationship with energy intensity in Eastern Europe where, possibly due to the impact of the market-oriented policy approach implemented in this region which facilitated trade inflow during the transition period from communism into market economies in the early 1990s.

We investigate whether the determining factors yield different impacts on energy intensity in some energy-intensive subsectors that are exposed to emission reduction policy. We consider three subsectors; paper, non-metallic product and basic metal, which are covered by the EU ETS and compare these subsectors with the chemicals industry, which was not covered by the ETS during our sample period. Consistent with our earlier findings, the fixed effects results presented in Table 5 shows that the coefficients of energy price are all negative and statistically significant in the price symmetric model. However, these subsectors have a lower price effect on energy intensity when compared with the price elasticity of the chemicals industry. This could partly be explained that these subsectors have internalized energy efficiency due to the emission policy in place, which makes energy intensity in these industries less responsive to energy price. Again, this finding supports our fifth hypothesis, H5.2, that we expect subsectors covered by the ETS to exhibit different responses in terms of reduction in energy intensity than other sectors not covered. In other words, the chemical industry seems to be more susceptible to energy prices relative to other ETS-covered energy-intensive industries, which underscores the hypothesis that non-ETS-covered sectors have a lower price elasticity than those energy-intensive sectors covered by the ETS.

Similarly, for the price asymmetric model, reduction in energy intensity is also associated with price-max, as it is negative and robust across the three ETS-covered subsectors, as well as in the chemicals industry. Unlike the average patent effect seen for the energy-intensive industries in Table 3, we cannot establish any significant impact on energy intensity from patent stock in either model. This also applies to the interaction of patent with energy maximum price, except for the non-metallic industry in asymmetric price model. However, since our sample only covers the first phase (2005-7) and the first two years of the second phase (2008-12) of the ETS, this might be responsible for the lack of clear impact of technological innovation on these industries. Nevertheless, the asymmetric price model shows estimated coefficients of interaction terms between patent and price recovery for basic paper and metal industries appear to be significant. Again, the magnitude of the positive coefficient of trade openness for chemical industry further reinforces our earlier findings that trade induces specialization in more energy-intensive industries. Another notable observation is the statistical significance and negative effect on energy intensity of growth in value added growth rate and the share of gas and electricity. The statistical significance of the coefficients of both vari- 


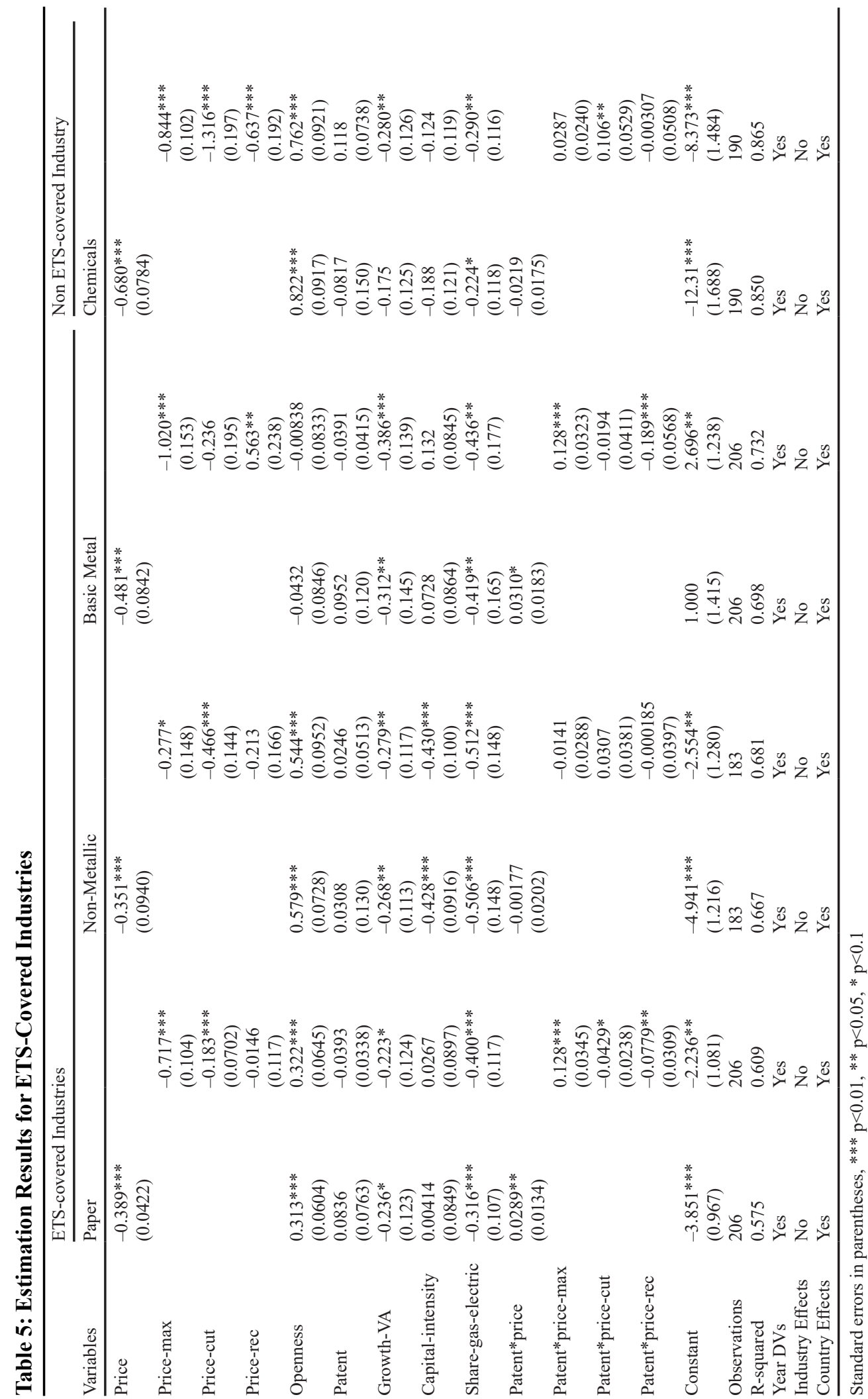


ables is clear across the four subsectors, indicating a decrease in energy intensity as output expands at current level of inputs, and as fuel mix tilts in favor of gas and electricity.

\section{CONCLUSION}

Energy intensity in the EU manufacturing sector has witnessed a substantial decline over the last three decades. A great deal of debate about the factors determining energy intensity has centered on the decomposed efficiency change indices, as opposed to the direct effect of technological innovation. The implication of technological effects arising from the decomposition analysis is the tendency within each sector to reduce energy intensity, which may not necessarily imply adoption of more efficient technologies. Hence, we have focused here on the direct impact of technology innovation instead of the broader concept of technological effects, which captures very diverse drivers. We investigate the impact of several factors that might plausibly influence energy intensity across 12 industries in $17 \mathrm{EU}$ countries.

Our findings show energy price remains the major determinant of energy intensity across EU manufacturing industries, although industry-level results show that energy intensity falls more in response to higher price than it does in less energy-intensive industries. We also establish that an increase in patent stock consistently leads to a fall in overall industrial energy intensity, with a much stronger effect in energy-intensive industries with an estimated coefficient of -0.138 , which nearly double that of less energy-intensive industries with an estimated parameter of -0.085 . The result suggests that heavy industries rely more on innovation in reducing energy intensity compared with light industries. Technological innovation induced by rising energy prices, as measured by the patent and price interaction, is consistently associated with a decline in manufacturing energy intensity. In particular, our study shows that the decline in energy intensity is much more sensitive to maximum price changes than price cut, offering evidence of an asymmetric response of efficiency to energy prices in which price rises between 2004 and 2008 of the sample period result in greater efficiency improvements.

Furthermore, our analysis of regional disparities indicates the implementation of a carbon tax significantly reduced energy intensity in Northern Europe. We find a clear negative relationship between the level of the carbon tax and energy intensity in those countries where a carbon tax has been imposed, which supports our fifth hypothesis. The cumulative effect of carbon taxes over the years following its implementation in the Nordic countries in the early 1990s appears to have caused energy intensity to fall by encouraging the adoption of low carbon and energy-saving technologies. The chemicals industry, in particular, seems to be more susceptible to energy prices relative to other energy-intensive industries which are covered by the ETS, which underscores the hypothesis that non ETS-covered sectors have a lower price elasticity than those energy-intensive sectors covered by the ETS. In addition, the impact of patent stock also exhibits different outcomes across regions, with negative impacts on energy intensity established for only Southern Europe and Northern Europe, which could be explained by different environmental and energy policy strategies being pursued by firms and national governments in those regions.

Overall, our study offers some policy implications, which might influence the future trajectory of manufacturing energy intensity in the EU. First, technological innovation offers potential opportunities for reducing energy intensity and developing new lower carbon-emission technologies, especially in energy-intensive industries. Policies such as targeted research and development incentives that encourage greater investments in innovation should be explored. 
Second, the ETS encourages efficiency improvement and in so doing, reduces the susceptibility of energy-intensive industries to energy prices. Although, the policy could increase the risk of leakage as inefficient firms who should be responsive to energy price are instead driven out of the market. The ETS reforms that came into force in early 2019 (Newbery et al., 2019) offer the prospect of a stronger price signal, which could lead both to greater low-carbon investments potential and to heightened concerns over leakage. To avoid concerns over leakage there have been a number of alternatives considered. For example, in the run up to the climate negotiations at Copenhagen in 2009, faced with the potential of not reaching an overarching deal, some advocated the notion of sectoral emissions agreements (Colombier and Neuhoff, 2008) whereas others focused on the potential use of border tax adjustments (van Asselt and Brewer, 2010).

Third, the complementarity of unilateral national climate policies with EU ETS policy could play a crucial role in consolidating emission abatement strategies, as the example of the carbon taxes adopted in the Nordic states illustrates since they played a crucial role in their achieving deep reductions in energy intensity. Individual national policies can either affect the overall price environment such as a carbon price floor (Newbery et al., 2019) or targeted climate actions for industry. The Dutch, for example, have been exploring a number of measures to address industrial carbon emissions, particularly in the Rotterdam cluster (Bosman et al., 2018).

Fourth, the frequency of adjustments in climate change policy in line with changing global energy price will influence potential energy savings, for instance, in less energy-intensive industries. This is important as global energy prices have continued to decline due to technological progress such as fracking which has made unconventional oil readily available in the energy market. Of course, this has implications for the petroleum industry and its attendant knock-on impact of exacerbating global emissions. The study also reveals a potential increase in energy intensity arising from international trade. Hence, we recommend reduced government interventions, particularly in the form of state aid, which exist in some of these sectors which could further weaken efficiency improvement effort or worsen carbon leakage that increases global emissions. Finally, governmental initiatives for energy conservation in the industrial sector that are meant to accelerate investments in clean technologies is recommended.

\section{ACKNOWLEDGMENTS}

The authors acknowledge support from the UK Engineering and Physical Sciences Research Council (EPSRC), grant number EP/N024567/1 and Dr Peter Neuhäusler of the Fraunhofer Institute for Systems and Innovation Research ISI in Karlsruhe, Germany, for providing industry-level patent data. We thank the reviewers and editor for their valuable comments which have improved the clarity and robustness of the arguments.

\section{REFERENCES}

Abernathy, W.J. and J.M. Utterback (1978). "Patterns of industrial innovation." Technology review 80(7): 40-47.

Abrell, J. (2010) "Regulating CO2 emissions of transportation in Europe: A CGE-analysis using market-based instruments." Transportation Research Part D: Transport and Environment 15(4): 235-239. https://doi.org/10.1016/j.trd.2010.02.002.

Adetutu, M.O., A.J. Glass, and T.G. Weyman-Jones (2016). "Decomposing energy demand across BRIIC countries." Energy Economics 54: 396-404. https://doi.org/10.1016/j.eneco.2016.01.001.

Adeyemi, O.I. and L.C. Hunt (2007). "Modelling OECD industrial energy demand: asymmetric price responses and energy-saving technical change." Energy Economics 29(4): 693-709. https://doi.org/10.1016/j.eneco.2007.01.007.

Adeyemi, O.I. and L.C. Hunt (2014). "Accounting for asymmetric price responses and underlying energy demand trends in OECD industrial energy demand.” Energy Economics 45: 435-444. https://doi.org/10.1016/j.eneco.2014.07.012. 
Aghion, P., A. Dechezleprêtre, D. Hemous, R. Martin and, J. Van Reenen (2016). "Carbon taxes, path dependency, and directed technical change: Evidence from the auto industry." Journal of Political Economy 124(1): 1-51. https://doi. org/10.1086/684581.

Ang, B.W. and F.Q. Zhang (2000). "A survey of index decomposition analysis in energy and environmental studies.” Energy 25(12): 1149-1176. https://doi.org/10.1016/S0360-5442(00)00039-6.

Atalla, T. and P. Bean (2017). Determinants of energy productivity in 39 countries: An empirical investigation. Energy Economics 62: 217-229. https://doi.org/10.1016/j.eneco.2016.12.003.

Bernard, A.B., V. Smeets, and F. Warzynski (2017). "Rethinking deindustrialization.” Economic Policy 32(89): 5-38 https:// doi.org/10.1093/epolic/eiw016.

Birol, F. and J.H. Keppler (2000). "Prices, technology development and the rebound effect." Energy Policy 28(6-7): 457-469. https://doi.org/10.1016/S0301-4215(00)00020-3.

Blind, K. and A. Jungmittag (2008). "The impact of patents and standards on macroeconomic growth: a panel approach covering four countries and 12 sectors." Journal of Productivity Analysis 29(1): 51-60. https://doi.org/10.1007/s11123007-0060-8.

Bosman, R., D. Loorbach, J. Rotmans, and R. van Raak (2018). “Carbon Lock-Out: Leading the Fossil Port of Rotterdam into Transition.” Sustainability 10(7): 2558. https://doi.org/10.3390/su10072558.

Calel, R. and A. Dechezleprêtre (2016). "Environmental policy and directed technological change: evidence from the European carbon market." Review of Economics and Statistics 98(1): 173-191. https://doi.org/10.1162/REST_a_00470.

Centre for European Policy Studies (CEPS) (2014). "Composition and Drivers of Energy Prices and Costs in Energy Intensive Industries: The Case of Ceramics. Flat Glass and Chemical Industries.” CEPS Special Report, Brussels.

Coe, D.T. and E. Helpman (1995). "International R\&D Spillovers.” European Economic Review 39(5): 859-887. https://doi. org/10.1016/0014-2921(94)00100-E.

Colombier, M. and K. Neuhoff (2008). Sectoral Emission Agreements: Can they Address Leakage? Environmental Policy and Law 38(3):161.

Dargay, J.M. and D. Gately (1995). "The imperfect price-reversibility of non-transport oil demand in the OECD.” Energy Economics 17(1): 59-71. https://doi.org/10.1016/0140-9883(95)98907-L.

Demailly, D. and P. Quirion, (2006). "CO2 abatement, competitiveness and leakage in the European cement industry under the EU ETS: grandfathering versus output-based allocation.” Climate Policy 6(1): 93-113. https://oi.org/10.3763/ cpol.2006.0606.

Diewert, W.E. (2001). "The consumer price index and index number theory: a survey." Journal of Economic and Social Measurement 27: 167-248. https://doi.org/10.3233/JEM-2003-0183.

Dolphin, G.G., M.G. Pollitt, and D.G. Newbery (2016). "The political economy of carbon pricing: a panel analysis." https:// doi.org/10.17863/CAM.7825.

European Bank for Reconstruction and Development, (2010). "Transition Report 2010: Recovery and Reform." Report of the Office of the Chief Economist, European Bank for Reconstruction and Development, London. Available on: http://www. ebrd.com/downloads/research/transition/tr10.pdf.

Eberhardt, M., C. Helmers, and H. Strauss (2013). "Do spillovers matter when estimating private returns to R\&D?" Review of Economics and Statistics 95(2): 436-448. https://doi.org/10.1162/REST_a_00272.

European Council (2013). The European Council in 2013. Available on: https://www.consilium.europa.eu/media/21303/ qcao13001enc.pdf (Accessed on 4 April 2018).

Filippini, M. and L.C. Hunt (2012). "US residential energy demand and energy efficiency: A stochastic demand frontier approach.” Energy Economics 34(5):1484-1491. https://doi.org/10.1016/j.eneco.2012.06.013.

Fisher-Vanden, K., Y. Hu, G. Jefferson, M. Rock, and M. Toman (2016). "Factors influencing energy intensity in four Chinese industries.” The Energy Journal 37(1): 153 -178. https://doi.org/10.5547/01956574.37.SI1.kfis.

Gallagher, K.S., A. Grübler, L. Kuhl, G. Nemet, and C. Wilson (2012). “The energy technology innovation system.” Annual Review of Environment and Resources 37: 137-162. https://doi.org/10.1146/annurev-environ-060311-133915.

Gately, D. and H.G. Huntington (2002). "The asymmetric effects of changes in price and income on energy and oil demand." The Energy Journal 23(1): 19-55. https://doi.org/10.5547/ISSN0195-6574-EJ-Vol23-No1-2.

Griffin, J.M. and C.T. Schulman (2005). "Price asymmetry in energy demand models: a proxy for energy-saving technical change?” The Energy Journal 26(1): 1-21. https://doi.org/10.5547/ISSN0195-6574-EJ-Vol26-No2-1.

Griffith, R., E. Huergo, J. Mairesse, and B. Peters (2006). "Innovation and productivity across four European countries." Oxford Review of Economic Policy 22(4): 483-498. https://doi.org/10.1093/oxrep/grj028.

Hang, L., and M. Tu (2007). "The impacts of energy prices on energy intensity: Evidence from China.” Energy policy 35(5): 2978-2988. https://doi.org/10.1016/j.enpol.2006.10.022. 
Heeley, M.B., A. Khorana, and S.F. Matusik (2000). "Underpricing and the Long-run Financial Performance of IPOs: Information Asymmetry and Firm Incentive Capability.” In: Reynolds D (ed.) Frontiers of Entrepreneurship Research-Proceedings of the 19th Annual Entrepreneurship Research Conference 1999, Babson College.

Hausman, J.A. (1978). “Specification tests in econometrics.” Econometrica 46: 1251-1271. https://doi.org/10.2307/1913827.

Hofer, H., R. Hyee, S. Loretz, S. Müllbacher, M. Baldini, G. Gallo, I. Styczyńska, G. Aydilek, T. Valkonen, S. Adam, and D. Philips (2015). "Study on the effects and incidence of labour taxation". Final Report. European Commission Taxation Papers Working Paper No 56.

Hübler, M. and A. Glas (2014). “The Energy-Bias of North-South Technology Spillovers: A Global, Bilateral, Bisectoral Trade Analysis.” Environmental and Resource Economics 58(1): 59-89. https://doi.org/10.1007/s10640-013-9690-7.

Huntington, H.G. (2006). "A note on price asymmetry as induced technical change.” The Energy Journal 27: 1-7. https://doi. org/10.5547/ISSN0195-6574-EJ-Vol27-No3-1.

Huntington, H.G. (2010). "Structural change and U.S. energy use: recent patterns.” The Energy Journal 31: 25-39. https:// doi.org/10.5547/ISSN0195-6574-EJ-Vol31-No3-2.

Jaffe, A.B., R.G., Newell and R.N. Stavins (2004). "Economics of energy efficiency." Encyclopedia of Energy 2: 79-90. https://doi.org/10.1016/B0-12-176480-X/00228-X.

Jimenez, R. and J. Mercado (2014). "Energy intensity: a decomposition and counterfactual exercise for Latin American countries." Energy Economics 42: 161-171. https://doi.org/10.1016/j.eneco.2013.12.015.

Johnstone, N., I. Haščič, and D. Popp (2010). "Renewable energy policies and technological innovation: evidence based on patent counts." Environmental and Resource Economics 45(1): 133-155. https://doi.org/10.1007/s10640-009-9309-1.

Karimu, A., R. Brännlund, T. Lundgren, and P. Söderholm (2017). "Energy intensity and convergence in Swedish industry: A combined econometric and decomposition analysis.” Energy Economics 62:347-356. https://doi.org/10.1016/j. eneco.2016.07.017.

Lescaroux, F. (2008). "Decomposition of US manufacturing energy intensity and elasticities of components with respect to energy prices.” Energy Economics 30: 1068-1080. https://doi.org/10.1016/j.eneco.2007.11.002.

Liddle, B. (2012). "The importance of energy quality in energy intensive manufacturing: Evidence from panel cointegration and panel FMOLS.” Energy Economics 34(6): 1819-1825. https://doi.org/10.1016/j.eneco.2012.07.013.

Löschel, A., F. Pothen and M. Schymura, (2015). "Peeling the onion: Analyzing aggregate, national and sectoral energy intensity in the European Union. Energy Economics 52: S63-S75. https://doi.org/10.1016/j.eneco.2015.09.004.

Ma, H., L. Oxley and J. Gibson (2009). "Substitution possibilities and determinants of energy intensity for China." Energy Policy 37(5): 1793-1804. https://doi.org/10.1016/j.enpol.2009.01.017.

Marrero, G. and F. Ramos-Real (2013). "Activity sectors and energy intensity: decomposition analysis and policy implications for European countries (1991-2005).” Energies 6(5): 2521-2540. https://doi.org/10.3390/en6052521.

Metcalf, G.E. (2008). "An empirical analysis of energy intensity and its determinants at the state level.” The Energy Journal 29(3): 1-26. https://doi.org/10.5547/ISSN0195-6574-EJ-Vol29-No3-1.

Mulder, P. (2015). "International specialization, sector structure and the evolution of manufacturing energy intensity in OECD countries.” The Energy Journal 36(3): 111-136. https://doi.org/10.5547/01956574.36.3.pmul.

Mulder, P. and H.L.F. de Groot (2012). "Structural change and convergence of energy intensity across OECD countries, 1970-2005.” Energy Economics 34: 1910-1921. https://doi.org/10.1016/j.eneco.2012.07.023.

Mulder, P., H.L.F. de Groot, and B. Pfeiffer (2014). "Dynamics and determinants of energy intensity in the service sector: a cross-country analysis, 1980-2005." Ecological Economics 100: 1-15. https://doi.org/10.1016/j.ecolecon.2014.01.016.

Newbery, D.M., D.M. Reiner, and R.A. Ritz (2019). "The Political Economy of a Carbon Price Floor for Power Generation." The Energy Journal 40(1): 1-24. https://doi.org/10.5547/01956574.40.1.dnew.

Organisation for Economic Cooperation and Development (2011). "STAN Database for Structural Analysis" (ISIC Rev. 3, 2008), STAN: OECD Structural Analysis Statistics (database).

Olaniyan, M.J. and J. Evans (2014). "The importance of engaging residential energy customers' hearts and minds." Energy Policy 69: 273-284. https://doi.org/10.1016/j.enpol.2013.12.023.

Oseni, M.O. (2009). "Analysis of energy intensity and its determinants in 16 OECD countries." Journal of Energy and Development 35(1/2): 101-140.

Parker, S. and B. Liddle (2016). "Energy efficiency in the manufacturing sector of the OECD: Analysis of price elasticities." Energy Economics 58: 38-45. https://doi.org/10.1016/j.eneco.2016.06.003.

Popp, D.C. (2001). "The effect of new technology on energy consumption." Resource and Energy Economics 23(3): 215-239. https://doi.org/10.1016/S0928-7655(00)00045-2.

Popp, D. (2006). "International innovation and diffusion of air pollution control technologies: the effects of NOX and SO2 regulation in the US, Japan, and Germany." Journal of Environmental Economics and Management 51(1): 46-71. https:// doi.org/10.1016/j.jeem.2005.04.006. 
Sato, M. and A. Dechezleprêtre (2015). “Asymmetric industrial energy prices and international trade.” Energy Economics 52: S130-S141. https://doi.org/10.1016/j.eneco.2015.08.020.

Sato, M., K. Neuhoff, V. Graichen, K. Schumacher and F. Matthes (2015). "Sectors under scrutiny: evaluation of indicators to assess the risk of carbon leakage in the UK and Germany." Environmental and Resource Economics 60(1): 99-124. https:// doi.org/10.1007/s10640-014-9759-y.

Schettkat, R. and L. Yocarini, (2006). "The shift to services employment: A review of the literature." Structural change and economic dynamics 17(2):127-147. https://doi.org/10.1016/j.strueco.2005.04.002.

Sharimakin, A., A.J. Glass, D.S. Saal, and K. Glass (2018). "Dynamic Multilevel Modelling of Industrial Energy Demand in Europe.” Energy Economics 74:120-130. https://doi.org/10.1016/j.eneco.2018.06.001.

Steinbuks, J. and K. Neuhoff (2014). "Assessing energy price induced improvements in efficiency of capital in OECD manufacturing industries.” Journal of Environmental Economics and Management 68(2): 340-356. https://doi.org/10.1016/j. jeem.2014.07.003.

Song, C. and Oh, W. (2015). "Determinants of innovation in energy intensive industry and implications for energy policy." Energy Policy 81: 122-130. https://doi.org/10.1016/j.enpol.2015.02.022.

Stöllinger, R. (2016). "Structural change and global value chains in the EU." Empirical Journal of European Economics 43(4): 801-829. https://doi.org/10.1007/s10663-016-9349-z.

Timmer, M.P., E. Dietzenbacher, B. Los, R. Stehrer, and G.J. Vries (2015). “An illustrated user guide to the world input-output database: the case of global automotive production.” Review of International Economics 23(3): 575-605. https://doi. org/10.1111/roie.12178.

Ulku, H. (2007). "R\&D, innovation, and growth: evidence from four manufacturing sectors in OECD countries." Oxford Economic Papers 59(3): 513-535. https://doi.org/10.1093/oep/gpl022.

Unander, F. (2007). "Decomposition of manufacturing energy-use in IEA countries: how do recent developments compare with historical long-term trends?" Applied Energy 84: 771-780. https://doi.org/10.1016/j.apenergy.2007.01.008.

van Asselt, H. and T. Brewer (2010). “Addressing competitiveness and leakage concerns in climate policy: An analysis of border adjustment measures in the US and the EU.” Energy Policy 38(1): 42-51. https://doi.org/10.1016/j.enpol.2009.08.061.

Van Looy, B., C. Vereyen, and U. Schmoch (2014). "Patent Statistics: Concordance IPC V8-NACE Rev. 2." Eurostat, European Commission, Luxembourg.

Voigt, S., E. De Cian, M. Schymura, and E. Verdolini (2014). "Energy intensity developments in 40 major economies: structural change or technology improvement?" Energy Economics 41: 47-62. https://doi.org/10.1016/j.eneco.2013.10.015.

Welsch, H. and C. Ochsen (2005). "The determinants of aggregate energy use in West Germany: factor substitution, technological change, and trade.” Energy Economics 27(1): 93-111. https://doi.org/10.1016/j.eneco.2004.11.004.

World Bank; Ecofys; Vivid Economics (2016). State and Trends of Carbon Pricing 2016. Washington, DC: World Bank. https://openknowledge.worldbank.org/handle/10986/25160 License: CC BY 3.0 IGO.

Wu, Y. (2012). "Energy intensity and its determinants in China's regional economies.” Energy Policy 41: 703-711. https://doi. org/10.1016/j.enpol.2011.11.034.

Zhang, F. (2013). “The energy transition of the transition economies: An empirical analysis.” Energy Economics 40: 679-686. https://doi.org/10.1016/j.eneco.2013.09.001.

Zheng, Y., J. Qi, and X. Chen (2011). "The effect of increasing exports on industrial energy intensity in China." Energy Policy 39(5): 2688-2698. https://doi.org/10.1016/j.enpol.2011.02.038.

Zylicz, T. (2013). "Choosing efficient combinations of policy instruments for low-carbon development and innovation to achieve Europe's 2050 climate targets." Country report: Poland. Cecilia 2050 Optimal EU Climate Policy. Available on https://cecilia2050.eu/system/files/\%C5\%BBylicz\%20\%282013\%29_Country\%20Report\%20-\%20Poland.pdf. 